\title{
Peningkatan Kosakata Bahasa Inggris dengan Media Ular Tangga bagi Siswa SD Antonius 2 Semarang
}

Increasing The English Vocabularies with Snake-Ladder Media for The Elementary School Students of Antonius 2 Semarang

\author{
Maria Theresia Priyastuti ${ }^{1}$, Mike Resanti ${ }^{2}$, Guido Shyantica Yoga $\mathrm{H}^{3}$ \\ ${ }^{1,2,3}$ Prodi S1 Ilmu Keperawatan, STIKes St. Elisabeth Semarang \\ E-mail: 1'priyastuti.maria@gmail.com, ${ }^{2}$ resantimike@gmail.com, ${ }^{3}$ deepsubmergee@gmail.com
}

\begin{abstract}
Abstrak
Bahasa Inggris merupakan salah satu mata pelajaran yang wajib dikuasai oleh siswa Sekolah Dasar. Namun siswa mengalami kesulitan berkomunikasi karena kurangnya penguasaan kosakata bahasa Inggris. Hal ini didukung pula dengan pembelajaran di sekolah yang lebih banyak menggunakan buku teks daripada menggunakan metode pembelajaran lain yang lebih menarik sehingga kegiatan pengabdian masyarakat ini perlu dilakukan di SD Antonius 2 Semarang. Tujuan dari kegiatan pengabdian masyarakat ini adalah untuk melatih siswa sekolah dasar berkomunikasi dalam bahasa Inggris untuk mengembangkan pengetahuan dan ketrampilan kosakata dengan penggunaan media ular tangga.. Metode pelaksanaan kegiatan dilaksanakan melalui pelatihan dengan pelaksanaan penelitian tindakan kelas, yang meliputi tahapan perencanaan, pelaksanaan, evaluasi dan refleksi. Dengan penggunaan media ular tangga, siswa SD Antonius 2 Semarang semakin terlatih berbicara bahasa Inggris dan menguasai banyak kosakata bahasa Inggris yang ada di sekitar lingkungan mereka.
\end{abstract}

Kata kunci: kosakata, bahasa Inggris, media, ular tangga

\begin{abstract}
English is one of the subjects that must be mastered by the Elementary School students. But students have difficulty communicating due to lack of mastery of the English vocabularies. This is also supported by learning in schools that uses more textbooks rather than using other learning methods that are more interesting so that this community service activity needs to be done at Antonius 2 Semarang Elementary School. The purpose of this community service activity is to train the Elementary School students to communicate in English to develop vocabulary knowledge and skills with the use of snake ladder media. The method of implementing activities is done through training of conducting classroom action research, which includes the stages of planning, implementation, evaluation and reflection. With the use of snake ladder media, the Elementary School students of Antonius 2 Semarang are increasingly trained to speak English and master many English vocabularies around their environment.
\end{abstract}

Keywords: vocabularies, English, media, snake ladder

\section{PENDAHULUAN}

Pelajaran Bahasa Inggis merupakan salah satu momok bagi beberapa siswa sehingga perlu mencari cara supaya proses pelajaran lebih efektif dapat berlangsung dengan lancar sehingga peserta didik dapat terbantu untuk belajar menguasai kosakata dalam bahasa Inggris. Penguasaan kosakata merupakan syarat utama kemampuan yang harus dimiliki oleh para siswa dalam proses mempelajari bahasa Inggris karena semakin banyak kosakata yang dimiliki maka semakin lancar komunikasi, dan semakin besar ketrampilan berbahasanya namun terkadang penguasaan kosakata tersebut sering tidak diperhatikan [1]. Penguasaan kosakata dapat diterapkan oleh guru dengan baik jika guru dapat menentukan metode dan pendekatan pembelajaran yang sesuai dengan usia dan tingkat kemampuan 
siswa siswa dalam menerima pembelajaran sehingga siswa dapat memahami kosakata yang telah diajarkan [2].

Selain itu, guru juga mampu menerapkan strategi pembelajaran bahasa Inggris yang menyenangkan dan tepat bagi para siswanya dengan salah satunya merancang media pembelajaran yang kreatif, menarik, tidak membosankan dan tidak monoton bagi para siswa. Media pembelajaran dapat digunakan untuk merangsang pikiran, perasaan, perhatian, minat dan perhatian siswa karena dapat menyampaikan pesan dari pengirim ke penerima dalam proses pembelajaran [3]. Media juga memberikan manfaat yang besar didalam kegiatan pembelajaran untuk memotivasi dan membangkitkan minat belajar siswa dalam menguasai kosakata bahasa Inggris [4].

Berdasarkan analisis situasi, media pembelajaran yang digunakan dalam proses pembelajaran bahasa Inggris di SD Antonius 2 Semarang masih kurang maksimal. Alat peraga yang digunakan dalam proses pembelajaran bahasa Inggris pun masih minim. Padahal alat peraga dirasakan sangat penting supaya dapat menarik minat siswa untuk mempelajari bahasa Inggris dan menumbuhkan minat belajar bagi para siswa. Proses pembelajaran bahasa Inggris yang dilakukan masih bersifat ceramah dan sebagian besar pelajaran bahasa Inggris di kelas dilakukan oleh guru dengan menggunakan buku teks sebagai sumber belajar. Akibatnya para siswa menganggap bahasa Inggris sebagai pelajaran yang sukar dan menimbulkan kebosanan atau tidak bersemangat dalam mempelajarinya. Selain itu, siswa menjadi sering lupa untuk menyebutkan kosakata dalam bahasa Inggris khususnya nama-nama benda yang telah dipelajarinya.

Dari permasalahan yang dihadapi oleh SD Antonius 2 Semarang yaitu kurangnya perbendaharaan kosakata bahasa Inggris yang dimiliki oleh para siswa serta minim ketersediaan media atau alat peraga pembelajaran dalam proses pembelajaran bahasa Inggris maka diperlukan metode lain yang dapat membangun pengetahuan siswa dalam meningkatkan perbendaharaan kosakata bahasa Inggris yang dimiliki dengan cara yang menarik dan menyenangkan. Salah satu media yang menarik dan menyenangkan adalah media permainan. Permainan mampu memberikan beberapa keuntungan, seperti bertambahnya pengetahuan, dan pengalaman nyata bagi siswa. Pelajaran bahasa Inggris yang diberikan dapat diterima secara menyenangkan, dan dapat membangkitkan minat yang besar bagi siswa terhadap topik tertentu. Permainan yang didesain dengan baik akan mengembangkan keterampilan siswa dalam hal tertentu, karena siswa menyukai hal tersebut. Penggunaan permainan dapat membuat siswa lebih mudah mempelajari ketrampilan dalam proses pembelajaran daripada melalui penyampaian materi secara biasa [3]. Media permainan ini lebih disukai siswa daripada metode ceramah, karena pada dasarnya anak-anak lebih menyukai permainan [5]. Permainan memiliki manfaat praktis yaitu membantu pertumbuhan fisik, mengendalikan emosi, mengembangkan keterampilan berbahasa, merangsang kreativitas, belajar bersosialisasi, mengetahui standar moral, dan mendukung perkembangan kognitif anak usia sekolah [6]. Melalui media permainan para siswa mampu berinteraksi, berkomunikasi secara lisan dan meningkatkan kemampuan berbahasa Inggris terutama dalam hal peningkatkan kosakata yang baik dan benar.

Salah satu permainan edukatif yang dipilih sesuai dengan pertimbangan permasalahan yang muncul di SD Antonius 2 Semarang adalah permainan ular tangga. Ular tangga merupakan permainan anak-anak yang terdiri atas papan permainan dimainkan oleh sejumlah orang (2 orang atau lebih) [7]. Permainan ular tangga dapat dibuat oleh para siswa sendiri sehingga menimbulkan kreativitas siswa dan kemampuan bekerja sama. Salah satu fungsi permainan ular tangga dapat menjadi alat komunikasi yang interaktif antar pemain [8]. Permainan ular tangga inilah yang menjadi salah satu pilihan atau alternatif permainan bagi para siswa di SD Antonius 2 Semarang untuk meningkatkan kemampuan mereka dalam menggunakan kosakata.

\section{METODE PELAKSANAAN}

Metode pelaksanaan kegiatan Pengabdian Kesehatan Masyarakat dilakukan dengan memberikan pelatihan peningkatan kosakata bahasa Inggris dan pembuatan media ular tangga sederhana dengan mengadopsi langkah-langkah atau tahapan action research, yaitu :

1. Perencanaan

Kegiatan-kegiatan yang dilakukan dalam tahap perencanaan adalah : 
a. Tim pengabdian masyarakat melakukan observasi langsung ke Sekolah Dasar Antonius 2 Semarang untuk mengidentifikasi, menganalisis permasalahan, kebutuhan dan potensi sekolah yang ada

b. Tim pengabdian masyarakat mengadakan pertemuan terkait pembekalan mengenai tujuan, rancangan mekanisme pelaksanaan pengabdian masyarakat dan penyusunan program pengabdian masyarakat terkait pembuatan dan pengimplementasian media permainan ular tangga untuk meningkatkan kosakata bahasa Inggris bagi siswa SD Antonius 2 Semarang.

c. Tim pengabdian masyarakat mengajukan ijin dan melakukan kontrak waktu pelaksanaan pengabdian masyarakat ke pihak Sekolah Dasar Antonius 2 Semarang

2. Tindakan

Tindakan dalam kegiatan Pengabdian Kesehatan Masyarakat ini berupa implementasi program kegiatan pengabdian masyarakat yang diberikan dalam bentuk pelatihan untuk:

a. Menambah perbendaharaan kosakata (vocabulary) bahasa Inggris yang dimiliki oleh siswa

b. Mendesain/merancang dan mengimplementasikan media papan permainan ular tangga berbahasa Inggris yang kreatif dan bervariatif yaitu papan permainan yang bergaris kotakkotak yang memuat berbagai macam gambar benda, bahan penyerta yang berisi petunjuk pemakaian, panduan penggunaan, tujuan pembelajaran untuk memudahkan guru dan siswa dalam menggunakan permainan ular tangga, dan kartu jawaban yang berisi kata-kata benda dalam Bahasa Inggris

c. Mengimplementasikan media permainan ular tangga dengan cara bermain secara berkelompok untuk melatih ketrampilan berbicara siswa

Berikut ini adalah diagram proses perancangan media permainan ular tangga untuk meningkatkan kosakata bahasa Inggris di Sekolah Dasar Antonius 2 Semarang.

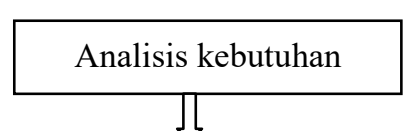

Analisis karakteristik siswa dan peningkatan kosakata bahasa Inggris anak sekolah dasar yang membutuhkan media permainan yang kreatif dan inovatif

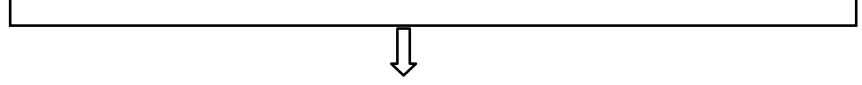

\section{Persiapan Proses Hasil}

\begin{tabular}{|c|c|c|c|c|}
\hline $\begin{array}{ll}- & \text { Alat peraga } \\
- & \text { bahan } \\
- & \text { alat kerja } \\
- & \text { langkah } \\
& \text { pembuatan dan } \\
\text { penggunaan }\end{array}$ & $\Longrightarrow$ & $\begin{array}{l}\text { Proses pembuatan media } \\
\text { permainan ular tangga dalam } \\
\text { bahasa Inggris untuk } \\
\text { meningkatkan kosakata bahasa } \\
\text { Inggris bagi para siswa dan } \\
\text { guru secara berkelompok }\end{array}$ & $\Longrightarrow$ & $\begin{array}{l}\text { Media gambar } \\
\text { permainan ular } \\
\text { tangga dalam } \\
\text { Inggris dengan } \\
\text { memanfaatkan } \\
\text { IPTEKS }\end{array}$ \\
\hline
\end{tabular}

Gambar 1 diagram proses perancangan media permainan ular tangga

Berdasarkan diagaram di atas maka dilakukan cara membuat media permainan ular tangga yaitu :

a. Proses pembuatan media ular tangga

1) Bahan yang digunakan adalah kertas karton, kertas asturo, kertas origami, penghapus karet.

2) Alat kerja yang digunakan adalah komputer, printer, modem, flashdisk, pensil, pulpen, penggaris, spidol, gunting/cutter, lem kertas

b. Langkah pembuatan papan permainan ular tangga :

1) Menyiapkan karton putih, penggaris, dan pensil terlebih dahulu.

2) Membuat garis kotak-kotak pada karton sesuai ukuran sebanyak 30 kotak dengan ukuran masing - masing $10 \times 10 \mathrm{~cm}$

3) Menggunting dan menempelkan kertas origami, kertas asturo, gambar flashcards disetiap kotak dengan warna yang berbeda-beda

4) Menuliskan angka/nomor urut dan huruf-huruf dan kosakata dengan spidol.

5) Menghias dengan gambar flashcards di beberapa sudut karton 
6) Membuat gambar ular dan tangga dengan spidol sesuai dengan jumlah sesuai keinginan pembuat.

c. Penggunaan alat peraga diberikan kepada siswa SD Antonius Kelas III dan indikator keberhasilan program kegiatan ini adalah siswa dapat menyebutkan, mengucapkan kosakata yang ada di dalam permainan ular tangga dengan intonasi yang benar atau siswa mengerti nama-nama benda dalam bahasa Inggris dengan benar. Prasyarat yang harus dimiliki siswa dalam kegiatan pengabdian masyarakat ini adalah

1) Menebak gambar sesuai dengan gambar benda di papan ular tangga

2) mengucapkan/mengeja nama-nama benda dalam bahasa Inggris.

3) menuliskan nama-nama benda dalam bahasa Inggris.

4) mencocokkan nama-nama benda dalam bahasa Inggris dengan gambar yang sesuai.

d. Langkah-langkah penggunaan media permainan ular tangga :

1) Para pemain meletakkan bidak pada papan permainan ular tangga vocabulary for all simple words yang bertuliskan kata "start"

2) Setiap pemain mengocok dadu untuk menentukan berapa langkah yang harus dijalankan.

3) Pemain harus melangkah sesuai dengan jumlah mata dadu yang keluar. Setelah berhenti disalah satu kotak, pemain dapat langsung menebak, mengucapkan dan menuliskan nama benda Bahasa Inggris yang tercantum di papan ular tangga. Jika pemain tersebut tidak tahu apa nama benda dalam bahasa Inggrisnya maka pemain dapat melihat di kartu jawaban dengan cara mencocokkan dan menyamakan nomor kotak dengan nomor yang ada di kartu jawaban.

4) Langkah permainan diatas dilakukan secara bergantian oleh setiap pemain sampai di kotak terakhir yang bertuliskan kata "finish". Pemain yang dapat menyelesaikan permainan paling cepat di kata "finish" adalah pemenangnya

3. Observasi dan evaluasi

Observasi dilakukan terhadap guru dan siswa untuk mempraktekkan pembuatan/perancangan dan pengimplementasian media permainan ular tangga dalam pembelajaran bahasa Inggris. Instrumen yang digunakan berupa catatan lapangan. Beberapa hal yang diobservasi adalah kendala atau kekurangan yang muncul selama proses pembuatan/perancangan dan pengimplementasian media permainan ular tangga untuk meningkatkan kosakata bahasa Inggris siswa sekolah dasar di lapangan. Evaluasi dilakukan terhadap keluaran yang dihasilkan.

4. Refleksi

Refleksi dilakukan terhadap kegiatan yang telah dilaksanakan. Hal ini dilakukan semata-mata untuk mengetahui kekurangan atau kelebihan terhadap kegiatan pengabdian kepada masyarakat yang telah dilakukan dalam rangka untuk menetapkan rekomendasi terhadap keberlangsungan kegiatan pengabdian masyarakat selanjutnya.

\section{HASIL DAN PEMBAHASAN}

Hasil yang dicapai melalui kegiatan pengabdian masyarakat ini dituangkan dalam bentuk hasil kegiatan pada setiap tahap pelaksanaan sebagai berikut :

1. Perencanaan

Kegiatan yang telah dilakukan pada tahap perencanaan adalah sebagai berikut :

a. Tim pengabdian masyarakat mengadakan pertemuan untuk membahas mengenai tujuan dan rancangan mekanisme pelaksanaan pengabdian masyarakat serta pertanggungjawaban pada pihak yayasan.

b. Berdasarkan hasil identifikasi, hasil analisis masalah yang ada, selanjutnya tim pelaksana melaksanakan program pengabdian masyarakat pada hari Jumat, tanggal 5 Agustus 2016 di ruang auditorium SD Antonius 2 Semarang. Jumlah total siswa kelas III SD Antonius 2 Semarang yang mengikuti kegiatan 73 siswa. Kegiatan pengabdian masyarakat dimulai dari pukul 09:00 - 12.30 WIB. 
2. Pelaksanaan Kegiatan

Tindakan dalam kegiatan ini berupa implementasi program. Tim pelaksana pengabdian masyarakat yang terdiri atas 5 orang membagi 73 siswa menjadi 15 kelompok dan masing-masing pelaksana membimbing 3 kelompok siswa untuk membuat papan ular tangga dan berlatih memainkan ular tangga yang telah dibuat untuk meningkatkan kosakata bahasa Inggris siswa kelas III SD Antonius 2 Semarang.

Kegiatan yang dilakukan tim pelaksana pengabdian masyarakat dalam implementasi program adalah sebagai berikut :

a. Mengajak siswa mengembangkan kemampuan kosakata bahasa Inggris.
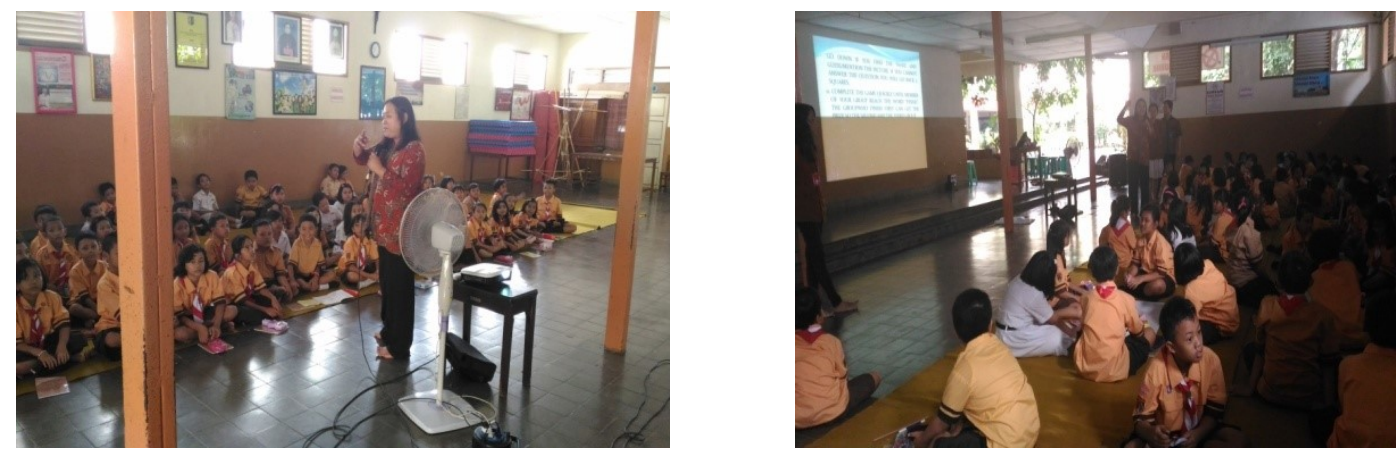

Gambar 2 dan 3 siswa diberikan pemahaman kosakata bahasa Inggris dan media ular tangga

b. Mengajak siswa membuat media ular tangga untuk memperkaya kosakata bahasa Inggris.
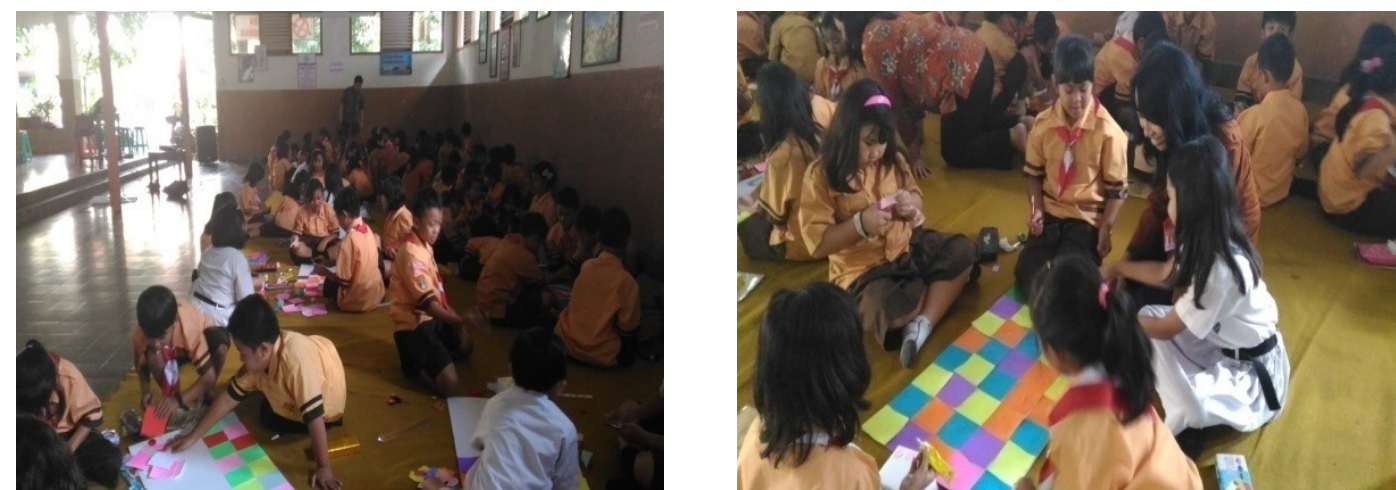

Gambar 3 dan 4 siswa membuat media permainan ular tangga

c. Mengajak siswa bekerja sama dalam membuat media dan bermain dengan suportif selama permainan berlangsung.
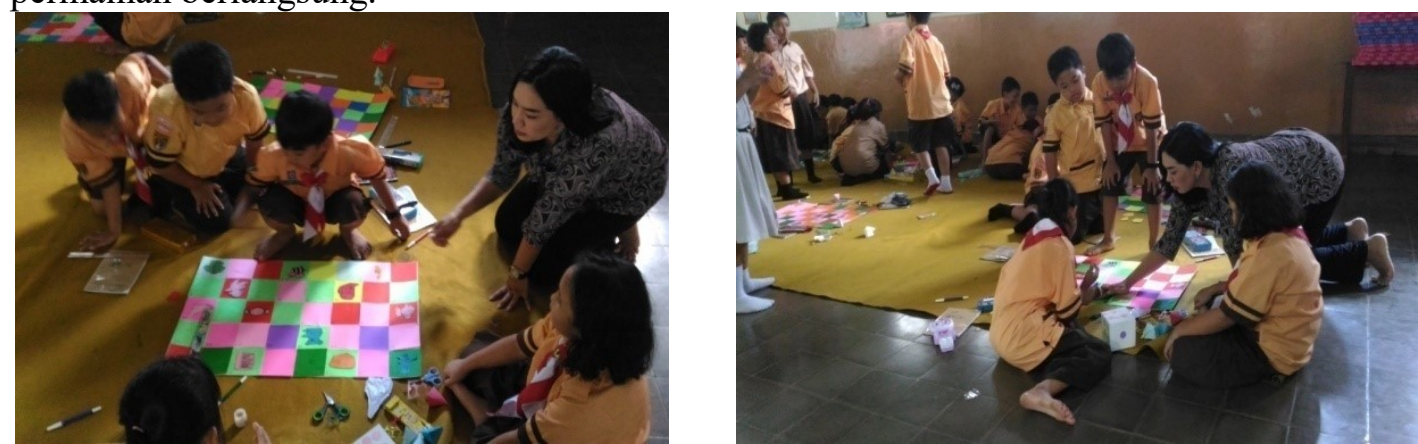

Gambar 5 dan 6 siswa melatih bermain media permainan ular tangga 
3. Observasi dan Evaluasi

Observasi dilakukan sebelum, selama dan setelah kegiatan pengabdian. Kegiatan pengabdian ini berlangsung lancar meskipun siswa sedikit sukar dikendalikan, akan tetapi rangkaian kegiatan berlangsung dengan baik. Seluruh siswa sangat senang mengikuti kegiatan ini. Hal ini dapat dilihat dari antusiasme mereka dalam membuat media peraga ular tangga dan melakukan permainan ular tangga. Selain itu siswa juga mampu menyebutkan dan mengingat kosakata bahasa Inggris khususnya kata benda yang digunakan dalam permainan ini dengan tepat. Tim pelaksana pengabdian masyarakat juga memberikan 3 buah hadiah bagi 3 juara dengan urutan juara I, II dan III bagi masing-masing kelompok yang telah menyelesaikan permainan ular tangga paling tepat dan cepat. Siswa sangat aktif dalam melakukan permainan hal ini dibuktikan dengan usaha setiap anggota kelompok dalam menjawab atau menyebutkan kata benda bahasa Inggris yang dijumpai dalam papan permainan ular tangga. Di akhir kegiatan berlangsung, banyak siswa masih asyik bermain ular tangga sehingga menimbulkan kegaduhan di kelas namun tim pelaksana dapat bekerja bersama wali kelas dengan baik dalam mengelola para siswa. Proses kegiatan pengabdian masyarakat dapat berlangsung dengan tertib dan aman.

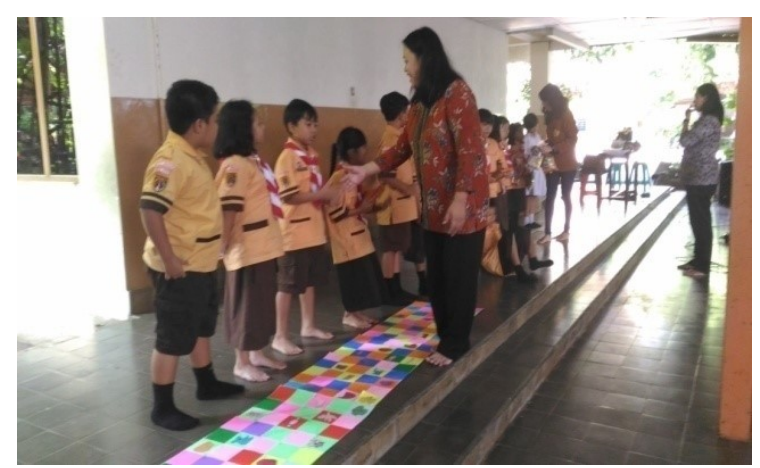

Gambar 7 kelompok siswa yang memenangkan permainan ular tangga

4. Refleksi

Hasil refleksi kegiatan ini berlangsung cukup baik, siswa masih perlu diberikan bekal pemahaman mendalam untuk membuat papan ular tangga yang baik dan penggunaan kosakata bahasa Inggris khususnya kata benda yang tepat sehingga permainan dengan media ular tangga dapat dilakukan dengan lebih menarik dan menyenangkan. Dalam kegiatan pengabdian masyarakat ini, diperlukan trik dan kiat khusus dalam menghadapi perilaku siswa di dalam kelas saat permainan ular tangga berlangsung sehingga pelaksanaan pengabdian ke depannya bisa berlangsung lebih tertib dan aman.

\section{KESIMPULAN DAN SARAN}

1. Kesimpulan yang dicapai melalui kegiatan pengabdian masyarakat ini adalah sebagai berikut.

a. Meningkatnya kosakata bahasa Inggris siswa SD Antonius 2 Semarang dengan menggunakan media permainan ular tangga yang menarik.

b. Meningkatnya pengetahuan dan pemahaman guru dan siswa untuk membuat media permainan ular tangga sendiri dalam pembelajaran bahasa Inggris dengan kosakata yang sederhana

2. Saran yang dapat disampaikan dalam kegiatan pengabdian masyarakat adalah

a. Para guru Sekolah Dasar dalam melaksanakan kegiatan pembelajaran bahasa Inggris, agar dapat menggunakan media permainan lain yang inovatif sehingga siswa termotivasi dan berminat untuk belajar kosakata bahasa Inggris 
b. Media pembelajaran melalui permainan ular tangga yang telah dihasilkan agar dapat dilaksanakan secara berkesinambungan dan dapat dilakukan pengembangan media pembelajaran bahasa Inggris lain sehingga kemampuan berpikir dan mengingat kosakata bahasa Inggris siswa Sekolah Dasar dapat berkembang dengan baik.

\section{UCAPAN TERIMA KASIH}

Pengabdian masyarakat ini terlaksana berkat bantuan dana dari Stikes St. Elisabeth Semarang melalui LPPM Stikes St. Elisabeth Semarang. Untuk itu dalam tulisan ini kami mengucapkan terima kasih kepada LPPM Stikes St. Elisabeth Semarang, tim pelaksana pengabdian masyarakat dan berbagai pihak yang terlibat dari SD Antonius 2 Semarang.

\section{DAFTAR PUSTAKA}

[1] Khasanah, P.M.A., Chamdani, \& Susiani, T.S., 2014, Upaya Meningkatkan Penguasaan Kosakata Bahasa Inggris melalui Penggunaan Media Kartu Domino Kata Bergambar Siswa Kelas V SD, Skripsi, FKIP PGSD, Universitas Sebelas Maret, Surakarta.

[2] Komachali, M.E. \& Khodareza, M., 2012, International Education Studies the Effect of Using Vocabulary Flash Card on Iranian Pre-University Students Vocabulary Knowledge, International Education Studies, No. 3, Vol. 5, May 8.

[3] Sadiman, Arief. dkk., 2014, Media Pendidikan : Pengertian, Pengembangan, dan Pemanfaatannya. PT Raja Grafindo Persada, Jakarta.

[4] Falahudin, I., 2014, Pemanfaatan Media dalam Pembelajaran, Jurnal Lingkar Widyaiswara, No. 4, hal. 104-117.

[5] Krisnawan, G. N. A., 2015, Rancang Bangun Aplikasi Game Edukasi Bahasa Inggris Untuk Anak Berbasis Android. Konferensi Nasional Sistem Dan Informatika, Bali, 9 - 10 Oktober.

[6] Dahlan, T., 2010, Games Sains Kreatif dan Menyenangkan, Ruang Kata, Bandung.

[7] Kusumawardhana., M.M., 2014, Pengembangan Media Pembelajaran dengan Aplikasi Adobe Flash CS4 Profesional Berbentuk Game Pendidikan Ular Tangga Pintar untuk Mata Pelajaran Pengantar Akuntansi dan Keuangan Kelas XI SMKN 2 Purworejo Tahun Ajaran 2014/2015. Skripsi. Fakultas Ekonomi, Universitas Negeri Yogyakarta, Yogyakarta.

[8] Nachiappan, S., Rahman, N., Andi, H., dan Zulkafaly, 2014, Snake and Ladder Games in Cognition Development on Students with Learning Difficulties. Review of Arts and Humanities, Vol.3, no.2, hal. 220. 